\title{
Multiple Sclerosis in Pediatrics: Current Concepts and Treatment Options
}

\author{
Jasna Jancic · Blazo Nikolic · Nikola Ivancevic · Vesna Djuric • \\ Ivan Zaletel · Dejan Stevanovic · Sasa Peric • \\ John N. van den Anker · Janko Samardzic
}

Received: July 21, 2016 / Published online: September 17, 2016

(C) The Author(s) 2016. This article is published with open access at Springerlink.com

\begin{abstract}
Multiple sclerosis (MS) is a chronic, autoimmune, inflammatory, demyelinating disease of the central nervous system. MS is increasingly recognized in the pediatric population, and it is usually diagnosed around 15 years of age. The exact etiology of MS is still not known, although autoimmune, genetic, and environmental factors play important roles in its
\end{abstract}

Enhanced content To view enhanced content for this article go to http://www.medengine.com/Redeem/ 8E76F0606ABD8139.

J. Jancic · B. Nikolic $\cdot$ N. Ivancevic $\cdot$ V. Djuric ·

D. Stevanovic

Clinic of Neurology and Psychiatry for Children and

Youth, Medical Faculty, University of Belgrade,

Belgrade, Serbia

\section{Zaletel}

Institute of Histology and Embryology "Aleksandar

Đ. Kostić", Medical Faculty, University of Belgrade,

Belgrade, Serbia

\section{S. Peric}

Clinic of Gastroenterology and Hepatology, Military

Medical Academy, Belgrade, Serbia

J. N. van den Anker · J. Samardzic

Division of Paediatric Pharmacology and

Pharmacometrics, University of Basel Children's

Hospital, Basel, Switzerland development, making it a multifactorial disease. The disease in children almost always presents in the relapsing-remittent form. The therapy involves treatment of relapses, and immunomodulatory and symptomatic treatment. The treatment of children with MS has to be multidisciplinary and include pediatric neurologists, ophthalmologists, psychologists, physiotherapists, and if necessary, pediatric psychiatrists and pharmacologists. The basis of MS therapy should rely on drugs that are able to modify the course of the disease, i.e. immunomodulatory drugs. These drugs can be

J. N. van den Anker

Division of Pediatric Clinical Pharmacology,

Children's National Medical Center, Washington,

DC, USA

J. N. van den Anker

Intensive Care and Department of Pediatric Surgery,

Erasmus MC Sophia Children's Hospital, Rotterdam,

The Netherlands

J. Samardzic $(\bowtie)$

Institute of Pharmacology, Clinical Pharmacology and Toxicology, Medical Faculty, University of Belgrade, Dr Subotica 1, 11129 Belgrade, Serbia e-mail: janko@med.bg.ac.rs 
subdivided into two general categories: first-line immunomodulatory therapy (interferon beta- $1 \mathrm{a}$, interferon beta- $1 \mathrm{~b}$, glatiramer acetate) and second-line immunomodulatory therapy (natalizumab, mitoxantrone, fingolimod, teriflunomide, azathioprine, rituximab, dimethyl fumarate, daclizumab). Treatment of relapses involves the use of high intravenous doses of corticosteroids, administration of intravenous immunoglobulins, and plasmapheresis. We summarize here the current available information related to the etiology and treatment options in MS. Early administration of immunomodulatory therapy is beneficial in adults, while more studies are needed to prove their effectiveness in pediatric populations. Therefore, pediatric MS still represents a great challenge for both, the early and correct diagnosis, as well as its treatment.

Keywords: Etiology;

Immunomodulatory therapy; Multiple sclerosis; Pediatrics; Treatment

\section{INTRODUCTION}

Multiple sclerosis (MS) is a chronic, autoimmune, inflammatory, demyelinating disease of the central nervous system [1]. The disease most often begins between the second and fourth decade of life, but it can also begin later, as well as in childhood. In recent years, MS is increasingly recognized in the pediatric population [2], in which clinical findings, magnetic resonance imaging (MRI), and laboratory analyses may vary significantly as compared to the adult population [3]. Therefore, new and emerging research in the field of pediatric MS is of crucial importance for both the early and correct diagnosis of pediatric MS, as well as its treatment. The first clinical and pathological description of MS was given by Prof. Jean-Martin Charcot in the nineteenth century, naming it sclerose en plaques [4]. A more intensive study of the etiology and pathophysiological processes underlying MS began before World War II, when an autoimmune theory was proposed, later followed by the discovery of the genetic basis of the disease [5-7]. The implementation of immunomodulatory therapy took place in the early nineties and it still is the first line of treatment in MS patients [5].

One of the main characteristics of MS is its geographic distribution [8], which is best illustrated by the fact that 50 percent of all MS patients are from Europe [9]. Results of different studies indicate an increase in the number of patients with MS since 1985, especially among women [9], although this can be partially explained by rapid advances in making the diagnosis of MS during recent decades. The assumption is that 2.3 million people in the world have MS [10], while $2.7-10.5 \%$ of all MS cases represent patients younger than 18 years of age [2]. Epidemiological studies indicate that there are areas with a high prevalence of MS $(>30 / 100,000)$ such as some northern Europe countries and North America, and areas with a low prevalence of MS $(<5 / 100,000)$ such as Africa, China, Japan, Latin and South America $[9,11]$. Sardinia is the place with the highest prevalence of the pediatric MS in the world [12]; however, the area with the highest prevalence of 300 per 100,000 is the Orkney Islands, including both adult and pediatric MS [8]. If we observe the American continent, MS is most common in non-Hispanic white individuals. Furthermore, in the last few years, pediatric MS becomes more common in African Americans than adult MS in the same population. African Americans have more severe clinical presentation compared to the white 
population if the disease starts early [13]. In the United States, the prevalence varies from 58 to 95 per 100,000. In pediatric hospitals in Canada, MS is increasingly diagnosed in ethnic populations, such as Caribbean, Asian, central and eastern European [14], more likely caused by genetics, environmental factors, infections, as well as inadequate exposure to sunlight, and consequently vitamin D deficiency. Namely, vitamin D deficiency or a polymorphism of vitamin $\mathrm{D}$ receptor gene diminishes its optimal function on the immune system that consequently could lead to increasing risk of MS [15]. However, its role in development and modulating the course of MS remains to be further elucidated.

Pediatric MS is usually diagnosed around 15 years of age [16], but one should be aware of its incidence in even younger children. Early onset of MS, i.e., in children who are below the age of 10 years, has a frequency rate around $0.2-0.7 \%$ [3], while the youngest patient diagnosed with MS was only 2 years old [2]. The sex ratio varies depending on the age, which could indicate that sex hormones play an important role in the pathogenesis of MS [17]. In early onset MS, the male to female ratio is almost $0.8-1$. Following the growth and the development of children, the ratio increases to $1: 2$ after the age of 10 years [3]. A positive family history has been shown in 6-20\% of children with MS [3].

\section{ETIOLOGY}

The exact etiology of MS is still not known, although autoimmune, genetic, and environmental factors play important roles in its development, making it a multifactorial disease [18]. Although more than 200 genes may impact the occurrence of MS, the most significant genetic factors contributing to the development of MS are changes in the human leukocyte antigen (HLA) DRB 1 gene [19]. In addition to the genetic background, the development of MS is also associated with Epstein-Barr virus (EBV) infection [20], low vitamin D levels [21], and smoking [22]. After contact with infectious agents, the immune system can activate autoreactive, circulating cluster of differentiation $4+(\mathrm{CD} 4+) \mathrm{T}$ lymphocytes. These cells may later differentiate into $\mathrm{T}$ helper (Th17) with the help of interleukin 23 (IL-23), which regulates the production of IL-17. The active cell can pass through the blood-brain barrier (BBB) and reacts with autoantigens, myelin antigens, or oligodendrocytes through the mechanism of molecular mimicry [23]. Th17 cells lead to the inflammation within the central nervous system (CNS), followed by migration of other $\mathrm{T}$ cells through the $\mathrm{BBB}$, and subsequent activation of macrophages. The production of pro-inflammatory cytokines during this immunological response damages myelin and oligodendrocytes, causing plaques of inflammatory demyelination, a hallmark of this disease [23, 24].

The course of MS is variable, but it represents probably one of the most detailed descriptions of all autoimmune disorders, ranging from a benign type of MS (minimal disability after 15 years of disease) to malignant forms of MS (severe disability or death after a few months) [25]. The various courses of MS are based on its clinical characteristics. Clinical events that characterize MS are relapse and/or progression. Relapses are defined as the occurrence, recurrence, or aggravation of neurological symptoms that last more than $24 \mathrm{~h}$ and occur at least 30 days after a previous attack. Between these relapses, neurological status may normalize or there may be still neurological sequelae [26]. Progression is characterized by the continuous deterioration in the past 6 months [27]. 
The clinical symptoms of the first attack, which last longer than $24 \mathrm{~h}$ and for which the differential diagnosis is assumed to be inflammatory demyelination with no evident signs of encephalopathy, is called a clinically isolated syndrome (CIS) [28]. According to some studies, $30-75 \%$ of patients with CIS will progress to MS $[29,30]$. The acquired demyelinating syndromes in the pediatric population were classified and defined in 2007 [31], and then updated in 2013 [26] by an international consensus group. In addition to CIS, a radiological isolated syndrome (RIS) was described in recent years, which indicate MRI changes that correspond to findings present in demyelinating diseases, but these changes do not correlate with clinical findings. According to some studies, approximately $20 \%$ of these patients will develop MS within the next 5 years [32]. The course of the disease leads to the development of brain atrophy and thus, loss of brain volume. In adults with MS, both global and regional brain atrophy develops gradually [33], as opposed to the pediatric MS, where most commonly regional brain atrophy develops [34] associated with cognitive and physical disabilities [35]. The analysis of cerebrospinal fluid in patients with pediatric MS can show negative oligoclonal bands in the beginning of the disease, but later they can be detected in over $90 \%$ of the cases [1]. The presence oligoclonal bands increases the risk of MS, but it is not exclusively specific for MS [1, 3].

The disease in children almost always presents in the relapsing-remittent form (RR) (85.7\% to even $100 \%$ of cases) and the majority of these patients fully recover from the initial attack $[2,36]$. Patients with RR MS, despite the growth of the degree of disability, are at no greater risk of a disease progression to the secondary progressive form [37]. In the pediatric population, the rate of recurrence in the first 3 years of the disease is higher than in adults [2]. Although the pediatric population has a higher number of relapses compared to adults, children also have faster recovery and slower disease progression when compared to adults [1]. The latest diagnostic techniques allow identification of the disease even in very young patients [38]. As in adults, patients in the pediatric age must exhibit at least two clinical demyelinating events, separated by at least 30 days, to be able to establish a diagnosis of MS. It is also important to exclude all other differential diagnostic causes which may correspond to the clinical picture [1]. The most common diseases that must be taken into account before establishing a definitive diagnosis of MS are presented in Fig. 1 $[1,39,40]$.

One of the main characteristics, a must for the diagnosis of MS, is the dissemination in space and time [1]. The diagnosis of MS in the pediatric population can be based on the revised McDonald's diagnostic criteria, but these criteria are not recommended to use in children younger than 12 years of age [1]. Consensus about the proposed definitions and diagnostic criteria for pediatric multiple sclerosis and related disorders was published in 2007 [31] and was later updated in 2013 [26]. To meet the requirements for the diagnosis, one should satisfy the following criteria, according to Krupp et al. [26, 41], Fig. 2.

Finally, the use of MRI as a diagnostic tool has a high sensitivity in the detection of the disease activity in both adults and in children. At the beginning of the disease, children can have multiple lesions on the MRI as compared to adults, especially in the cerebellum and brainstem [42]. Moreover, MRI findings are often correlated with the clinical picture and the degree of disability [17]. 


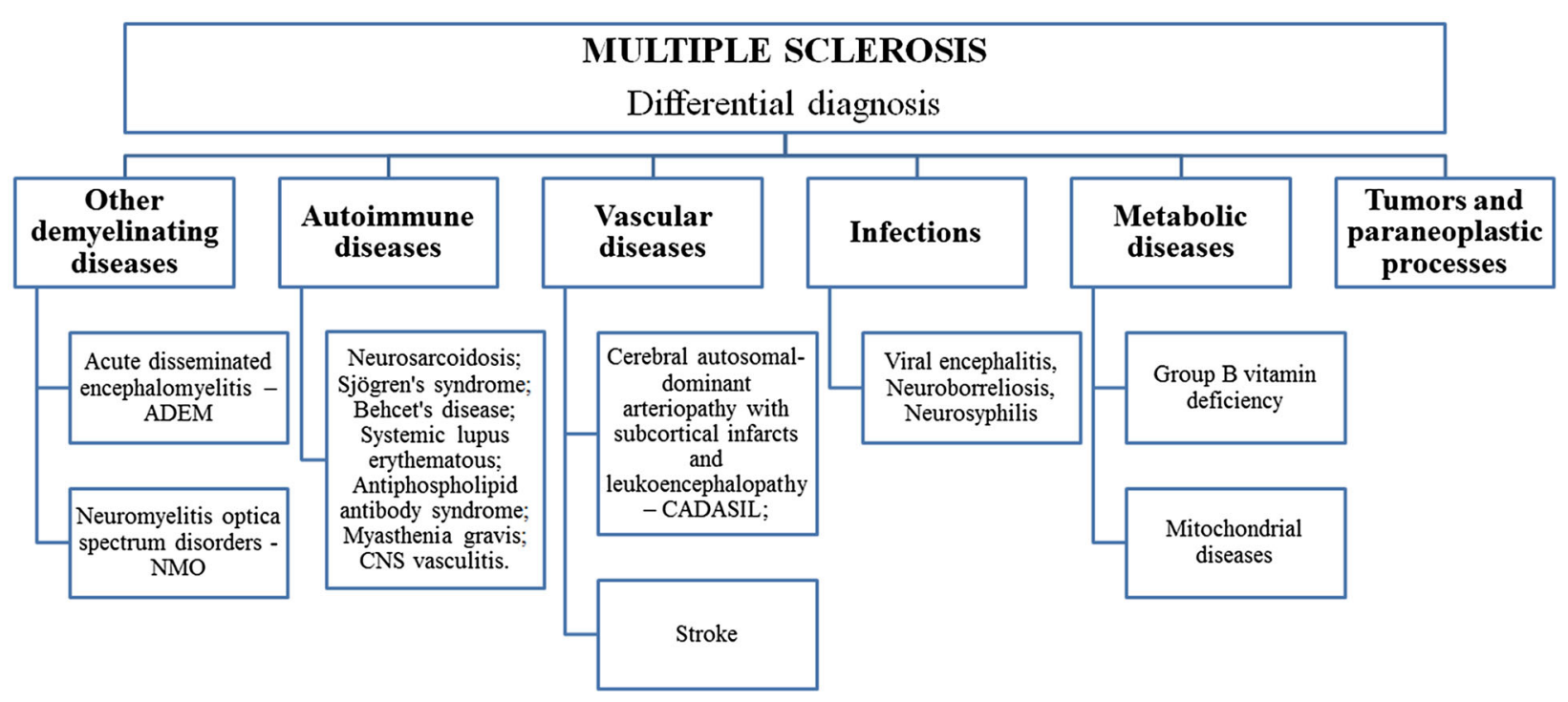

Fig. 1 Differential diagnosis of multiple sclerosis

\section{TREATMENT OF PEDIATRIC MS}

The therapy of pediatric MS involves treatment of relapses, and immunomodulatory and symptomatic treatment. The treatment of children with MS has to be multidisciplinary and has to include pediatric neurologists, ophthalmologists, psychologists, physiotherapists, and if necessary, pediatric psychiatrist and pharmacologist. This article is based on previously conducted studies and does not involve any new studies of human or animal subjects performed by any of the authors.

\section{Immunomodulatory Therapy}

The basis of MS therapy should rely on drugs that are able to modify the course of the disease, i.e. immunomodulatory drugs. These drugs can be subdivided into two general categories: first-line immunomodulatory therapy and second-line immunomodulatory therapy (Table 1). According to the current recommendations, pediatric patients with MS should be treated with these disease-modifying drugs, as early as possible [43].

\section{First-Line Immunomodulatory Therapy}

Drugs that modify the disease and can be given to children older than 12 years are interferon beta-1a (Avonex ${ }^{\circledR}$, Rebif $^{\circledR}$ ), interferon beta- $1 b$ $\left(\right.$ Betaferon $\left.{ }^{\circledR}\right)$, and glatiramer acetate $\left(\right.$ Copaxone ${ }^{\circledR}$ ). These drugs have been approved by the European Medicines Agency (EMA). Avonex $^{\circledR}$ is given once a week in a dose of $30 \mu$ g i.m., while Rebif ${ }^{\circledR}$ is administered three times a week in a dose of $22-44 \mu \mathrm{g}$, s.c. Interferon beta-1b is given every other day in a dose of $250 \mu \mathrm{g}$ s.c. and glatiramer acetate in a dose of $20 \mathrm{mg}$ also s.c. [44]. These drugs can reduce the number of relapses in adults up to $30 \%[2,51]$. Efficiency, effectiveness, and side effects of these drugs are based on data from clinical studies, but it is necessary to note that some studies are still ongoing [2]. All of these drugs have shown significant therapeutic effectiveness by reducing the frequency and severity of clinical relapses and disease activity 





4Fig. 2 Diagnostic criteria for adult and pediatric MS [magnetic resonance imaging (MRI), central nervous system (CNS), acute disseminated encephalomyelitis (ADEM), dissemination in space (DIS), dissemination in time (DIT)]

as shown by MRI of the brain, and are also able to reduce the degree of disability [44]. These drugs are well tolerated, but must be administered i.m. or s.c., which can be a problem for use in pediatric patients [2, 44, 51].

Interferon acts through specific receptors to regulate signaling cascades. Its effect is mediated through the inhibition of autoreactive $\mathrm{T}$ cell inhibition of pro-inflammatory cytokines, reduction of lymphocyte migration, and induction of anti-inflammatory mediators [2]. The most common side effects are flu-like symptoms, injection skin reaction, headache, myalgia, nausea, fatigue, increased liver enzyme values, and thyroid dysfunction [44]. In patients who have developed flu-like symptoms, ibuprofen or paracetamol can be used. The use of these drugs requires monitoring of hematological parameters and liver enzyme values each month during the first 6 months and then once every 3 months. Occasionally, it is also

Table 1 First-line and second-line immunomodulatory therapy (intramuscularly-i.m.; subcutaneously-s.c.; intravenously-i.v.; per os-p.o.)

\begin{tabular}{|c|c|c|c|c|}
\hline & Dose & $\begin{array}{l}\text { Mode of } \\
\text { application }\end{array}$ & Dosing regimen & References \\
\hline \multicolumn{5}{|c|}{ First-line immunomodulatory therapy } \\
\hline Interferon & $30 \mu \mathrm{g}$ & i.m. & Once a week & {$[43,44]$} \\
\hline beta-1a & $22-44 \mu \mathrm{g}$ & s.c. & $\begin{array}{l}\text { Three times a } \\
\text { week }\end{array}$ & {$[43,44]$} \\
\hline $\begin{array}{l}\text { Interferon } \\
\text { beta- } 1 b\end{array}$ & $250 \mu \mathrm{g}$ & s.c. & Every other day & {$[44]$} \\
\hline $\begin{array}{l}\text { Glatiramer } \\
\text { acetate }\end{array}$ & $20 \mathrm{mg}$ & s.c. & Once a day & {$[44]$} \\
\hline \multicolumn{5}{|c|}{ Second-line immunomodulatory therapy } \\
\hline Natalizumab & $3-5 \mathrm{mg} / \mathrm{kg}$ & i.v. & Once a month & {$[2,43,45]$} \\
\hline Mitoxantrone & $\begin{array}{l}\text { In a dose of } 10-20 \mathrm{mg}-\text { up to a total dose of } \\
200 \mathrm{mg}\end{array}$ & i.v. & $\begin{array}{l}\text { Once every } \\
3 \text { months }\end{array}$ & {$[46]$} \\
\hline Fingolimod & $0.5 \mathrm{mg}$ & p.o. & Once a day & {$[2]$} \\
\hline Teriflunomide & 7 and $14 \mathrm{mg}$ & p.o. & Once a day & {$[2]$} \\
\hline Azathioprine & $2.5-3 \mathrm{mg} / \mathrm{kg}$ & p.o. & Once a day & {$[46]$} \\
\hline Rituximab & $500-1000 \mathrm{mg}$ & i.v. & $\begin{array}{l}\text { Every } \\
\qquad 6-12 \text { months }\end{array}$ & {$[2,46]$} \\
\hline $\begin{array}{l}\text { Dimethyl } \\
\text { fumarate }\end{array}$ & Initial dose $120 \mathrm{mg}$, therapeutic dose $240 \mathrm{mg}$ & p.o. & Twice daily & {$[47,48]$} \\
\hline Daclizumab & $150 \mathrm{mg}$ & s.c. & Once a month & {$[49,50]$} \\
\hline
\end{tabular}


necessary to check thyroid function [52]. Based on published data observed side effects of s.c. administration of interferon beta-1a, in patients who were older than 12 and even in patients who were younger than 12 years, were: injection-site reactions, influenza-like symptoms, hepatic disorders, blood cell disorders (e.g. thrombocytopenia, leucopenia, anemia), elevations in alanine aminotransferase and aspartate aminotransferase concentrations, allergic reactions (e.g. rash, urticaria, anaphylaxis), epilepsy and convulsive disorders, thyroid dysfunction, autoimmune diseases, bone/epiphyseal and cartilage disorders, and serious infections [43].

Glatiramer acetate is relatively well-tolerated, even during long-term use [44]. Glatiramer acetate achieves its effect by inhibiting specific effector T-lymphocytes and influencing antigen-presenting cells and suppressor T-lymphocytes [2]. Some studies suggest that glatiramer acetate may cause a transient flushing-like reaction associated with tachycardia [52]. Recent studies on the use of glatiramer acetate in the pediatric population are scarce.

\section{Second-Line Immunomodulatory Therapy}

Second-line drugs are available only as a part of ongoing clinical studies. Natalizumab $\left(\right.$ Tysabri $\left.^{\circledR}\right)$ is a monoclonal antibody. The drug targets $\alpha 4 \beta 1$-integrin and blocks migration of Tand B-lymphocytes across the blood-brain barrier [2]. It is given once a month by intravenous infusion using a dose of $300 \mathrm{mg}$ [46] or $3-5 \mathrm{mg} / \mathrm{kg}$ [2]. Because of its high efficacy, it is able to reduce the activity of MS and its progression. Application of natalizumab is contraindicated in the pediatric population; however, according to some clinical trials, natalizumab was able to significantly decrease the disease activity and had fewer serious side effects in pediatric patients as compared to adults [53]. Although it reduces the number of relapses by $68 \%$ [46], this drug has a high risk of serious side effects, such as progressive multifocal leukoencephalopathy, hypersensitivity, and infections [2, 53, 54].

Mitoxantrone $\quad\left(\right.$ Novantrone $^{\circledR}$ ) is administered as an intravenous infusion once every 3 months using a dose of $10-20 \mathrm{mg}$ with a maximal dose of $200 \mathrm{mg}$ [46]. It is used in patients with an aggressive form of disease or in patients with severe cases of relapse remitting MS and secondary progressive MS [55]. The most common side effects of this drug are cardiotoxicity, leukopenia, nausea, infections, alopecia, fatigue, and amenorrhea [46, 55].

Fingolimod (Gylenia ${ }^{\circledR}$ ) tablets $(0.5 \mathrm{mg}$ ) are taken once daily orally which is a great advantage over drugs that have to be administered i.m or s.c.. The drug targets the sphingosine-1-phosphate receptor [2]. It has been used in adults since 2010, and its application in pediatric patients is being tested through clinical studies. Fingolimod has a higher efficcacy than first-line drugs, but is also associated with a risk of serious adverse effects. The most common side effects include abnormal heart rhythm after the first dose of drug and macular edema [56].

Teriflunomide $\left(\right.$ Aubagio $^{\circledR}$ ) has been accepted as yet another drug that can be given orally. Tablets of 7 and $14 \mathrm{mg}$ are administered once a day. Its safety profile is favorable and most common unwanted effects are alopecia and hepatotoxicity [2]. The results of the studies in pediatric patients are yet to be expected in the future.

Azathioprine is an immunosuppressive drug used in adults. The drug antagonizes purine metabolism and it is given orally in a dose of $2.5-3 \mathrm{mg} / \mathrm{kg} /$ day. The most common side 
effects are skin rashes, gastrointestinal symptoms, cytopenia, and liver toxicity. There is also a risk of cancer occurrence [46].

Cyclophosphamide $\quad\left(\right.$ Cytoxan $\left.^{\circledR}\right)$ is an immunosuppressive drug with cytotoxic effects. For the time being it is not given in the pediatric population for this indication. The most common side effects of this drug are vomiting, amenorrhea, transient alopecia and osteoporosis. Regular control in patients on cyclophosphamide therapy is necessary in order to prevent a possible development of amenorrhea, sterility, infections and malignancies $[2,46]$.

Rituximab $\quad$ Rituxan $^{\circledR}$ ) is chimeric monoclonal immunoglobulin G1 (IgG1)kappa antibody that targets the CD20 receptor on activated B lymphocytes. It has been shown to reduce relapses in adolescents. A few cases of progressive multifocal leukoencephalopathy (PML) have been reported in patients with systemic lupus erythematosus who were treated with this drug, which represents a serious and difficult side effect of this drug $[2,46]$. So far there are only few studies on the use of rituximab in pediatric patients with MS, which is why the recommendations for its administration do not exist, and therefore require further studies [57].

The mechanism of action of dimethyl fumarate $\left(\right.$ Tecfidera $^{\circledR}$ ) is still not fully known, but the drug has been shown to reduce cytokine production, lymphocyte count and result in reduction of migratory activity of immune cells through the BBB [58]. Monomethyl fumarate is the active metabolite of this drug [59]. Dimethyl fumarate is administered orally using a dose of $120 \mathrm{mg}$ and $240 \mathrm{mg}$ and is intended for the treatment of patients with relapsing forms of MS [47]. The most common and significant side-effects of dimethyl fumarate are itching, redness, nausea, vomiting, abdominal pain and diarrhea, lymphopenia, PML, allergic reaction, hives, rash, itching, hoarseness, and vision problems.

Daclizumab (Zinbryta $\left.{ }^{\circledR}\right)$ is administered once a month in a dose of $150 \mathrm{mg}$, s.c. Daclizumab is a monoclonal humanized antibody that selectively binds to the IL-2 receptor alpha-chain. The effect of daclizumab showed a reduced relapse rate and fewer new lesions on MRI [49, 50]. The most common and significant side-effects of daclizumab are serious infections, gastrointestinal disorders, depression, liver toxicity and elevations of liver enzymes, serious cutaneous events. So far there is only one study on the use of daclizumab in pediatric patients with MS. It reduces clinical and MRI disease activity in pediatric patients. Side-effects were mild $[49,50]$.

\section{Treatment of Relapses}

Treatment of relapses involves the use of high intravenous doses of corticosteroids such as the administration of methylprednisolone in doses of $20-30 \mathrm{mg} / \mathrm{kg}$ and up to $1000 \mathrm{mg}$ per day once a day in the morning. This treatment should last 3-5 days and needs to be supported by gastroprotective medications. Unlike in adults, pediatric neurologists can decide if there is a need for a short term extension of the corticosteroid treatment [1]. The use of corticosteroids this way reduces the number of side-effects to a minimum. Side effects of corticosteroid use in children are: mood disorders, insomnia, hypertension, and hyperglycemia [3]. If the administration of corticosteroids does not result in improvement of clinical findings, it can be replaced by a 5-day administration of intravenous immunoglobulins using a dose of $0.4 \mathrm{~g} / \mathrm{kg} /$ day. In addition, plasmapheresis is another therapeutic option if the previous forms of therapy did not result in satisfactory results [1]. 


\section{Treatment of Specific Symptoms}

Symptomatic therapy should be directed towards eliminating specific symptoms, which may occur in the course of the disease. The most common symptoms that occur in children are pain, anxiety, depression, fatigue, stiffness (spasm), interference with urination, and sexual dysfunction. If the symptoms of anxiety and depression are noticed, it is necessary to immediately include a pediatric or adolescent psychiatrist in order to prevent progression. Pain that occurs in MS patients is of neuropathic origin and should be treated according to the recommendations for the treatment of neuropathic pain (tricyclic antidepressants, gabapentin and pregabalin, 5\% lidocaine, and tramadol) [60].

\section{CONCLUSION}

Pediatric MS still represents a major diagnostic and therapeutic problem. Early administration of immunomodulatory therapy is beneficial in adults, while more studies are needed to prove their effectiveness in pediatric populations. Therefore, better knowledge of both the etiology and pathogenesis of pediatric MS is of great importance in search of the correct treatment.

\section{ACKNOWLEDGMENTS}

No funding or sponsorship was received for this study or publication of this article. All named authors meet the International Committee of Medical Journal Editors (ICMJE) criteria for authorship for this manuscript, take responsibility for the integrity of the work as a whole, and have given final approval for the version to be published.
Disclosures. Jasna Jancic is supported by the Ministry of Education, Science and Technological Development of the Republic of Serbia (Grant No: 175031). Janko Samardzic is supported by the Ministry of Education, Science and Technological Development of the Republic of Serbia (Grant No: 175076). John van den Anker is supported by NIH (K24DA027992, R01HD048689, U54HD071601) and the European Commission (TINN [223614], TINN2 [260908], NEUROSIS [223060]). All authors (Jasna Jancic, Blazo Nikolic, Nikola Ivancevic, Vesna Djuric, Ivan Zaletel, Dejan Stevanovic, Sasa Peric, John N. van den Anker, Janko Samardzic) declare no conflict of interest regarding the content of this manuscript.

Compliance with Ethics Guidelines. This article is based on previously conducted studies and does not involve any new studies of human or animal subjects performed by any of the authors.

Open Access. This article is distributed under the terms of the Creative Commons Attribution-NonCommercial 4.0 International License (http://creativecommons.org/licenses/ by-nc/4.0/), which permits any noncommercial use, distribution, and reproduction in any medium, provided you give appropriate credit to the original author(s) and the source, provide a link to the Creative Commons license, and indicate if changes were made.

\section{REFERENCES}

1. Pena JA, Lotze TE. Pediatric multiple sclerosis: current concepts and consensus definitions. Autoimmune Dis. 2013;2013:673947. doi:10.1155/ $2013 / 673947$. 
2. Chitnis T. Disease-modifying therapy of pediatric multiple sclerosis. Neurotherapeutics. 2013;10(1): 89-96. doi:10.1007/s13311-012-0158-1.

3. Patel Y, Bhise V, Krupp L. Pediatric multiple sclerosis. Ann Indian Acad Neurol. 2009;12(4):238-45. doi:10. 4103/0972-2327.58281.7.

4. Compston A. The 150th anniversary of the first depiction of the lesions of multiple sclerosis. J Neurol Neurosurg Psychiatry. 1988;51(10): 1249-52.

5. Orrell RW. Multiple sclerosis: the history of a disease. J R Soc Med. 2005;98(6):289.

6. Ebers GC. Environmental factors and multiple sclerosis. Lancet Neurol. 2008;7(3):268-77. doi:10. 1016/S1474-4422(08)70042-5.

7. Murray TJ. The history of multiple sclerosis: the changing frame of the disease over the centuries. J Neurol Sci. 2009;1(277 Suppl 1):S3-8. doi:10.1016/ S0022-510X(09)70003-6.

8. Sahraian MA, Pakdaman H, Harandi AA. Is it time to revise the classification of geographical distribution of multiple sclerosis? Iran J Neurol. 2012;11(2):77-8.

9. Kingwell E, Marriott JJ, Jetté N, Pringsheim T, Makhani N, Morrow SA, Fisk JD, Evans C, Béland SG, Kulaga S, Dykeman J, Wolfson C, Koch MW, Marrie RA. Incidence and prevalence of multiple sclerosis in Europe: a systematic review. BMC Neurol. 2013;26(13):128. doi:10.1186/1471-237713-128.

10. Browne $\mathrm{P}$, Chandraratna $\mathrm{D}$, Angood $\mathrm{C}$, Tremlett $\mathrm{H}$, Baker C, Taylor BV, Thompson AJ. Atlas of Multiple Sclerosis 2013: a growing global problem with widespread inequity. Neurology. 2014;83(11): 1022-4. doi:10.1212/WNL.0000000000000768.

11. Atlas of MS 2013: Mapping Multiple Sclerosis Around the World. London: Multiple Sclerosis International Federation. 2013. http://www.msif. org/wpcontent/uploads/2014/09/Atlas-of-MS.pdf/. Accessed 10 Oct 2013.

12. Dell'Avvento S, Sotgiu MA, Manca S, Sotgiu G, Sotgiu S. Epidemiology of multiple sclerosis in the pediatric population of Sardinia, Italy. Eur J Pediatr. 2016;175(1):19-29. doi:10.1007/s00431-015-25883.

13. Boster AL, Endress CF, Hreha SA, Caon C, Perumal JS, Khan OA. Pediatric-onset multiple sclerosis in African-American black and European-origin white patients. Pediatr Neurol. 2009;40(1):31-3. doi:10. 1016/j.pediatrneurol.2008.09.004.
14. Kennedy J, O'Connor P, Sadovnick AD, Perara M, Yee I, Banwell B. Age at onset of multiple sclerosis may be influenced by place of residence during childhood rather than ancestry. Neuroepidemiology. 2006;26(3):162-7.

15. Alharbi FM. Update in vitamin D and multiple sclerosis. Neurosciences (Riyadh). 2015;20(4): 329-35. doi:10.17712/nsj.2015.4.20150357.

16. Waldman A, Ghezzi A, Bar-Or A, Mikaeloff Y, Tardieu M, Banwell B. Multiple sclerosis in children: an update on clinical diagnosis, therapeutic strategies, and research. Lancet Neurol. 2014;13(9):936-48. doi:10.1016/S14744422(14)70093-6.

17. Chabas D, Green AJ, Waubant E. Pediatric multiple sclerosis. NeuroRx. 2006;3(2):264-75.

18. Bernard CC, de Rosbo NK. Multiple sclerosis: an autoimmune disease of multifactorial etiology. Curr Opin Immunol. 1992;4(6):760-5.

19. Cree BA. Multiple sclerosis genetics. Handb Clin Neurol. 2014;122:193-209. doi:10.1016/B978-0444-52001-2.00009-1.

20. Zhou Y, Zhu G, Charlesworth JC, Simpson S Jr, Rubicz R, Göring HH, Patsopoulos NA, Laverty C, $\mathrm{Wu} \mathrm{F}$, Henders A, Ellis JJ, van der Mei I, Montgomery GW, Blangero J, Curran JE, Johnson MP, Martin NG, Nyholt DR, Taylor BV, ANZgene consortium. Genetic loci for Epstein-Barr virus nuclear antigen-1 are associated with risk of multiple sclerosis. Mult Scler 2016; pii: 1352458515626598. [Epub ahead of print]

21. Faridar A, Eskandari G, Sahraian MA, Minagar A, Azimi A. Vitamin D and multiple sclerosis: a critical review and recommendations on treatment. Acta Neurol Belg. 2012;112(4):327-33. doi:10.1007/ s13760-012-0108-z.

22. Wingerchuk DM. Smoking: effects on multiple sclerosis susceptibility and disease progression. Ther Adv Neurol Disord. 2012;5(1):13-22. doi:10. $1177 / 1756285611425694$.

23. Loma I, Heyman R. Multiple sclerosis: pathogenesis and treatment. Curr Neuropharmacol. 2011;9(3): 409-16. doi:10.2174/157015911796557911.

24. Wu GF, Alvarez E. The immunopathophysiology of multiple sclerosis. Neurol Clin. 2011;29(2):257-78. doi:10.1016/j.ncl.2010.12.009.

25. Rejdak K, Jackson S, Giovannoni G. Multiple sclerosis: a practical overview for clinicians. Br Med Bull. 2010;95:79-104. doi:10.1093/bmb/ldq017. 
26. Krupp LB, Tardieu M, Amato MP, Banwell B, Chitnis T, Dale RC, Ghezzi A, Hintzen R, Kornberg A, Pohl D, Rostasy K, Tenembaum S. Wassmer E; International Pediatric Multiple Sclerosis Study Group. International Pediatric Multiple Sclerosis Study Group criteria for pediatric multiple sclerosis and immune-mediated central nervous system demyelinating disorders: revisions to the 2007 definitions. Mult Scler. 2013;19(10):1261-7. doi:10.1177/1352458513484547.

27. Petiot V, Quantin C, Le Teuff G, et al. Disability evolution in multiple sclerosis: how to deal with missing transition. Times in the Markov model? Neuroepidemiology. 2007;28:56-64.

28. Lee CG, Lee B, Lee J, Lee M. The natural course of clinically isolated syndrome in pediatric patients. Brain Dev. 2015;37(4):432-8. doi:10.1016/j. braindev.2014.07.005.

29. Miller D, Barkhof F, Montalban X, Thompson A, Filippi M. Clinically isolated syndromes suggestive of multiple sclerosis, part I: natural history, pathogenesis, diagnosis, and prognosis. Lancet Neurol. 2005;4:281-8.

30. Nilsson P, Larsson EM, Maly-Sundgren P, Perfekt R, Sandberg-Wollheim M. Predicting the outcome of optic neuritis: evaluation of risk factors after 30 years of follow-up. J Neurol. 2005;252:396-402.

31. Krupp LB, Banwell B, Tenembaum S, International Pediatric MS Study Group. Consensus definitions proposed for pediatric multiple sclerosis and related disorders. Neurology. 2007;68(16 Suppl 2):S7-12.

32. Okuda DT, Mowry EM, Beheshtian A, Waubant E, Baranzini SE, Goodin DS, Hauser SL, Pelletier D. Incidental MRI anomalies suggestive of multiple sclerosis: the radiologically isolated syndrome. Neurology. 2009;72(9):800-5. doi:10.1212/01.wnl. 0000335764.14513 .1 .

33. Radü EW, Bendfeldt K, Mueller-Lenke N, Magon S, Sprenger T. Brain atrophy: an in vivo measure of disease activity in multiple sclerosis. Swiss Med Wkly. 2013;21(143):w13887. doi:10.4414/smw. 2013.13887.

34. Aubert-Broche B, Fonov V, Ghassemi R, Narayanan S, Arnold DL, Banwell B, Sled JG, Collins DL. Regional brain atrophy in children with multiple sclerosis. Neuroimage. 2011;58(2):409-15. doi:10. 1016/j.neuroimage.2011.03.025.

35. Rojas JI, Patrucco L, Miguez J, Cristiano E. Brain atrophy in multiple sclerosis: therapeutic, cognitive and clinical impact. Arq Neuropsiquiatr. 2016; 74(3):235-43. doi:10.1590/0004-282X20160015.
36. Al-Hamadani HA, Abdalla AS, Al-Saffar AJ. The course of early-onset multiple sclerosis in Iraqi children. World J Pediatr. 2012;8(1):47-51. doi:10. 1007/s12519-011-0297-1.

37. Koch M, Kingwell E, Rieckmann P, Tremlett H, UBC MS Clinic Neurologists. The natural history of secondary progressive multiple sclerosis. J Neurol Neurosurg Psychiatry. 2010;81(9):1039-43. doi:10. 1136/jnnp.2010.208173.

38. Boiko A, Vorobeychick G, Paty D, et al. Early onset multiple sclerosis-a longitudinal study. Neurology. 2002;59:1006-10.

39. Jančić J, Dejanović I, Radovanović S, Ostojić J, Kozić D, Đurić-Jovičić M, Samardžić J, Ćetković M, Kostić V. White matter changes in two Leber's hereditary optic neuropathy pedigrees: 12-year follow-up. Ophthalmologica. 2016;235(1):49-56. doi:10. $1159 / 000441089$.

40. Dujmovic I, Jancic J, Dobricic V, Jankovic M, Novakovic I, Comabella M, Drulovic J. Are Leber's mitochondial DNA mutations associated with aquaporin-4 autoimmunity? Mult Scler. 2016;22(3):393-4. doi:10.1177/1352458515590649.

41. Polman $\mathrm{CH}$, Reingold SC, Banwell B, Clanet $\mathrm{M}$, Cohen JA, Filippi M, Fujihara K, Havrdova E, Hutchinson M, Kappos L, Lublin FD, Montalban $\mathrm{X}$, O'Connor P, Sandberg-Wollheim M, Thompson AJ, Waubant E, Weinshenker B, Wolinsky JS. Diagnostic criteria for multiple sclerosis: 2010 revisions to the McDonald criteria. Ann Neurol. 2011;69(2):292-302. doi:10.1002/ana.22366.

42. Waubant E, Chabas D. Pediatric multiple sclerosis. Curr Treat Options Neurol. 2009;11(3):203-10.

43. Tenembaum SN, Banwell B, Pohl D, Krupp LB, Boyko A, Meinel M, Lehr L, Rocak S, Cantogno EV, Moraga MS, Ghezzi A, REPLAY Study Group. Subcutaneous interferon Beta-1a in pediatric multiple sclerosis: a retrospective study. J Child Neurol. 2013;28(7):849-56. doi:10.1177/08830 73813488828 .

44. Ghezzi A. Therapeutic strategies in childhood multiple sclerosis. Ther Adv Neurol Disord. 2010;3(4):217-28. doi:10.1177/1756285610371251.

45. Ghezzi A, Moiola L, Pozzilli C, Brescia-Morra V, Gallo P, Grimaldi LM, Filippi M, G GC; MS Study Group-Italian Society of Neurology. Natalizumab in the pediatric MS population: results of the Italian registry. BMC Neurol. 2015;25(15):174. doi:10. 1186/s12883-015-0433-y.

46. Tenembaum SN. Therapy of multiple sclerosis in children and adolescents. Clin Neurol Neurosurg. 
2010;112(7):633-40. doi:10.1016/j.clineuro.2010. 04.015 .

47. Patti F, Leone C, Zappia M. Clinical and radiologic rebound after discontinuation of natalizumab therapy in a highly active multiple sclerosis patient was not halted by dimethyl-fumarate: a case report. BMC Neurol. 2015;7(15):252. doi:10. 1186/s12883-015-0512-0.

48. Makhani N, Schreiner T. Oral dimethyl fumarate in children with multiple sclerosis: a dual-center study. Pediatr Neurol. 2016;57:101-4. doi:10.1016/ j.pediatrneurol.2016.01.010.

49. Gorman MP, Tillema JM, Ciliax AM, Guttmann CR, Chitnis T. Daclizumab use in patients with pediatric multiple sclerosis. Arch Neurol. 2012;69(1):78-81. doi:10.1001/archneurol.2011.581.

50. Simone $\mathrm{M}$, Chitnis T. Use of disease-modifying therapies in pediatric MS. Curr Treat Options Neurol. 2016;18(8):36. doi:10.1007/s11940-016-0420-7.

51. Narula S, Hopkins SE, Banwell B. Treatment of pediatric multiple sclerosis. Curr Treat Options Neurol. 2015;17(3):336. doi:10.1007/s11940-0140336-z.

52. Banwell B, Ghezzi A, Bar-Or A, Mikaeloff Y, Tardieu M. Multiple sclerosis in children: clinical diagnosis, therapeutic strategies, and future directions. Lancet Neurol. 2007;6(10):887-902.

53. Kornek B. An update on the use of natalizumab in the treatment of multiple sclerosis: appropriate patient selection and special considerations. Patient Prefer Adherence. 2015;19(9):675-84. doi:10.2147/PPA.S20791.

54. Yeh EA. Management of children with multiple sclerosis. Paediatr Drugs. 2012;14(3):165-77. doi:10.2165/11596330-000000000-00000.
55. Etemadifar M, Afzali P, Abtahi SH, Ramagopalan SV, Nourian SM, Murray RT, Fereidan-Esfahani M. Safety and efficacy of mitoxantrone in pediatric patients with aggressive multiple sclerosis. Eur J Paediatr Neurol. 2014;18(2):119-25. doi:10.1016/j. ejpn.2013.09.001.

56. Fragoso YD, Alves-Leon SV, Barreira AA, Callegaro D, Ferreira MLB, Finkelsztejn A, Gomes S, Goncalves MVM, Machado MIM, Marques VD, Matta APC, Papais-Alvarenga RM, Pereira SLA, Tauil CB. Fingolimod prescribed for the treatment of multiple sclerosis in patients younger than age 18 years. Pediatr Neurol. 2015;53(2):166-8. doi:10. 1016/j.pediatrneurol.2015.03.024.

57. Beres SJ, Graves J, Waubant E. Rituximab use in pediatric central demyelinating disease. Pediatr Neurol. 2014;51(1):114-8. doi:10.1016/j. pediatrneurol.2014.02.007.

58. Gross CC, Schulte-Mecklenbeck A, Klinsing S, Posevitz-Fejfár A, Wiendl H, Klotz L. Dimethyl fumarate treatment alters circulating $\mathrm{T}$ helper cell subsets in multiple sclerosis. Neurol Neuroimmunol Neuroinflamm. 2015;3(1):e183. doi:10.1212/NXI. 0000000000000183.

59. Cada DJ, Levien TL, Baker DE. Dimethyl fumarate. Hosp Pharm. 2013;48(8):668-79. doi:10.1310/ hpj4808-668.

60. Dworkin RH, O'Connor AB, Audette J, Baron R, Gourlay GK, Haanpää ML, Kent JL, Krane EJ, Lebel AA, Levy RM, Mackey SC, Mayer J, Miaskowski C, Raja SN, Rice AS, Schmader KE, Stacey B, Stanos S, Treede RD, Turk DC, Walco GA, Wells CD. Recommendations for the pharmacological management of neuropathic pain: an overview and literature update. Mayo Clin Proc. 2010;85(3 Suppl):S3-14. doi:10.4065/mcp.2009.0649. 